\title{
Perception, Knowledge, and Professional Behavior of Dentists about Silver Diamine Flouride: A Nationwide Survey
}

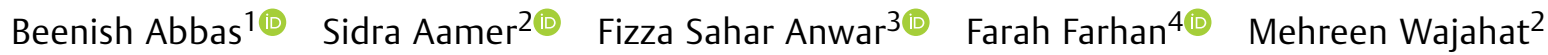 \\ Zohaib Khurshid ${ }^{50}$ \\ ${ }^{1}$ Department of Pedodontics, Foundation University, University of \\ Islamabad, Islamabad, Pakistan \\ 2 Department of Dental Materials, Foundation University, University \\ of Islamabad, Islamabad, Pakistan \\ ${ }^{3}$ Department of Medical Education, Foundation University, University \\ of Islamabad, Islamabad, Pakistan \\ Address for correspondence Beenish Abbas, BDS, FCPS, Foundation \\ University Islamabad, Islamabad, 45730, Pakistan \\ (e-mail: beenishabbas1982@gmail.com). \\ ${ }^{4}$ Department of Oral Pathology, Foundation University, University of \\ Islamabad, Islamabad, Pakistan \\ ${ }^{5}$ College of Dentistry, King Faisal University, Saudi Arabia
}

Eur J Gen Dent 2022;11:32-37.

\section{Abstract}

\section{Keywords}

- dental technology

- dentists

- silver diamine fluoride

Objectives The aim of this study was to survey the educational experiences, knowledge, and attitude of dentists in Pakistan about the professional use of silver diamine fluoride (SDF). This study also aimed to determine if SDF educational experience at the undergraduate level can result in a more positive attitude and increased clinical usage of SDF.

Materials and Methods This was a cross-sectional survey, conducted at multiple dental institutes across Pakistan using a pre-validated questionnaire to assess the knowledge, experience, and professional expertise of dentists regarding the use of SDF. The data were entered and analyzed using the SPSS (version 23.0) data management software by IBM.

Results The results of this study were deemed significant in terms of achievement of the study aims. The majority of the responders, 178 (79.8\%), reported online resources to be the main source of information about SDF treatment, whereas 103 (46.1\%) responders gained information from a dental journal. A higher number of consultants were reported to be well educated regarding SDF treatment during their residency training as compared with demonstrators, house officers, and postgraduate trainees $(p<0.001)$. About $64(28.7 \%)$ responders agreed that SDF is a better alternative treatment for children with behavioral issues, $74(33.2 \%)$ agreed that it is a better treatment option for medically fragile patients, and 79 (35.4\%) agreed that it can be used as an alternative for patients with dental anxiety. It was agreed by $82(36.8 \%)$ responders that SDF is a good treatment option for patients who recently have received chemotherapy radiation therapy.

Conclusion It is the need of time to put all educational efforts together to enhance knowledge regarding the use, advantages, and potential problems of SDF.
\end{abstract}

DOI https://doi.org/ $10.1055 / \mathrm{s}-0041-1739510$. ISSN 2320-4753. (c) 2021. The Author(s).

This is an open access article published by Thieme under the terms of the Creative Commons Attribution License, permitting unrestricted use, distribution, and reproduction so long as the original work is properly cited. (https://creativecommons.org/licenses/by/4.0/)

Thieme Medical and Scientific Publishers Pvt. Ltd., A-12, 2nd Floor, Sector 2, Noida-201301 UP, India 


\section{Introduction}

Dental caries is a biofilm-mediated multifactorial dynamic disease involving alternating cycles of demineralization and remineralization of enamel and dentine, with a better understanding of disease pathology, scientific evidence shows that demineralized tissue has the potential to remineralize with minimally invasive nonrestorative cavity treatment. ${ }^{1}$ Silver diamine fluoride (SDF) is a non-invasive, low-cost, antimicrobial solution and has remineralization potential used to arrest caries in ambulatory attendance of very young children, patients with special needs, or medically compromised individuals. ${ }^{2,3}$ Minimally invasive treatment such as SDF can improve the access to oral health care, improve the oral health status of not only young uncooperative patients but also medically vulnerable adult patients who are undergoing chemotherapy or on bisphosphonate treatment, ultimately reducing the need for emergency dental attendance. ${ }^{4}$ Silver particles are responsible for permanent staining of enamel and dentine. Potential for staining is significant impediment to usage of SDF. ${ }^{5}$ Recent evidence shows that the American Dental Association (ADA) and American Academy of Pediatric Dentistry (AAPD) recommend that $38 \%$ SDF should be used as a part of a comprehensive full-mouth rehabilitation plan in uncooperative child patient or those with special health care needs. ${ }^{3}$ Topical application of SDF without removing carious infected dentine can result in arresting of carious lesion, this treatment can serve as an alternative approach when conventional treatment is not possible due to severe behavior issues or medical complexity, thus reducing the need for dental care under general anesthesia with its associated adverse effects. $^{6,7}$ There is considerable evidence of successful usage of SDF for treating an active cavitated lesion in carious posterior primary teeth as an alternative minimally invasive biological treatment approach. ${ }^{2,8}$ However, the potential to discolor dental hard tissue and the need for repeated applications are considered as barriers for clinical usage of SDF. ${ }^{9}$ Twice a year, the application of $38 \%$ SDF solution can result in $84.8 \%$ arrest of carious lesions according to literature reports. ${ }^{3,10} \mathrm{SDF}$ is suggested as a minimally invasive treatment option for biomodification of repairable inner carious dentine a recent study by Firouzmandi et al shows that SDF increases microhardness and elastic modulus of caries affected dentine. ${ }^{11}$

There is a scarcity of data in clinical research in the Asia Pacific region regarding how well dental schools educate their students about clinical techniques and indications of SDF. Recent reports show $79.9 \%$ of U.S. pediatric dentistry programs have started to include SDF in their curriculum with a quarter of programs using it in clinical settings. ${ }^{12}$ There is a paucity of such evidence in the Asia Pacific region. The rationale of this study is to survey the educational experiences, knowledge, and attitude of dentists in Pakistan about the professional use of SDF. In specific, we sought to determine if SDF educational experience at the undergraduate level can result in a more positive attitude and increased clinical usage of SDF.

\section{Materials and Methods}

This cross-sectional survey was conducted at multiple dental institutes across Pakistan. Approval of the study was given by the Ethical Review Board Foundation University College of Dentistry. This study was conducted over a period of 6 months.

The intent of the study was to assess the knowledge, experience, and professional expertise of pediatric dentists regarding the use of SDF. A pilot questionnaire was distributed among 15 dentists from Academica for questionnaire validation and reviewed by independent experts for face validity. After comprehensive review and authentication, a final survey comprising four sections with close-ended questions was devised as a research tool. Section I was related to participants' sociodemographic data. Section II inquired about the education of SDF in dental schools, residency, dental journals, online resources, and continuum of education programs. Section III addressed participants' clinical knowledge on the use of SDF in various dental diseases. Section IV evaluated the dentist's attitude toward the employment of material as a treatment modality in various clinical scenarios such as among children with behavioral issues, fragile patients, and bisphosphonate medication.

The data were entered and analyzed using the SPSS (version 23.0) data management software by IBM. The descriptive statistics for age, gender, professional status, and rural/urban work area were presented as frequency and percentage. Similarly, frequency and percentage of responses to the education regarding SDF treatment, knowledge, and attitude toward SDF treatment questionnaire were reported. The group comparison between age, gender, working area, and professional employment status was done using the Chi-square test. The $p$-value of $\leq 0.05$ was considered significant in this study.

\section{Results}

Two hundred twenty-three $(n=223)$ dentists participated in the study. The majority of the dentists, i.e., 141 (63.2\%) belonged to the age group of 20 to 30 years, while the remaining one-third were of more than 30 years of age. There were 176 (78.9\%) female dentists, whereas 47 (21.2\%) were male dentists. In terms of employment status, 85 (38.1\%) were working in hospitals, 74 (33.2\%) were selfemployed in their own private practice, while 64 (28.7\%) had an academic appointment. The majority, i.e., 209 (93.7\%) dentists were working in urban settings, while 11 (4.9\%) were in rural areas. With respect to stage of professional development, there were 46 (20.6\%) consultants, 93 (41.7\%) demonstrators, 59 (26.5\%) postgraduate residents and 25 (11.2\%) house officers. Demographic characteristics of study responders are summarized in - Table $\mathbf{1}$.

- Table 2 summarizes the study responder's educational experience regarding SDF. In their academic training, 53 (23.8\%) responders reported that little was taught regarding SDF, while 138 (61.9\%) reported that no education was 
Table 1 Demographic characteristics of study responders $(n=223)$

\begin{tabular}{|c|c|c|}
\hline Characteristics & Frequency (n) & Percentage (\%) \\
\hline \multicolumn{3}{|l|}{ Age range } \\
\hline - $20-30 y$ & 141 & 63.2 \\
\hline - $31-40 y$ & 67 & 30.0 \\
\hline - $41-50 y$ & 15 & 6.7 \\
\hline \multicolumn{3}{|l|}{ Gender } \\
\hline - Male & 47 & 21.2 \\
\hline - Female & 176 & 78.9 \\
\hline \multicolumn{3}{|l|}{ Employment status } \\
\hline - Self employed & 74 & 33.2 \\
\hline - Hospital employed & 85 & 38.1 \\
\hline $\begin{array}{l}\text { - Academic } \\
\text { appointment }\end{array}$ & 64 & 28.7 \\
\hline \multicolumn{3}{|l|}{ Area } \\
\hline - Rural & 11 & 4.9 \\
\hline - Urban & 209 & 93.7 \\
\hline \multicolumn{3}{|l|}{ Professional status } \\
\hline - Consultant & 46 & 20.6 \\
\hline - Demonstrator & 93 & 41.7 \\
\hline - $\mathrm{PG}$ resident & 59 & 26.5 \\
\hline - House officer & 25 & 11.2 \\
\hline
\end{tabular}

provided about this subject. In dental school clinical settings, $38(17.0 \%)$ responders reported that a little education regarding SDF was provided, while 177 (79.4\%) reported no education was provided. During the residency program, 36 (16.1\%) reported that information about SDF was provided, while 187 (83.9\%) reported no provision of information. During continuing education programs, around 72 (32.2\%) responders reported the provision of educational information about SDF. After graduation, during continuing education courses, 151 (67.7\%) responders were not educated about SDF while the remaining received some education as shown in - Table 2. The majority of the responders, 178 (79.8\%) reported online resources to be the main source of information about SDF treatment, whereas 103 (46.1\%) responders gained information from a dental journal.

Knowledge about SDF was assessed by using 6-item selfreported questions, responses to which are summarized in -Table 3. The majority of the responders, 170 (76.2\%) reported that they were aware of SDF use in dentistry, 177 (79.3\%) were aware of SDF use in tooth hypersensitivity treatment, 207 (92.8\%) were aware of SDF use for the treatment of pediatric dental caries, and 153 (68.6\%) were aware of SDF use in adult dental caries. Around 65 (29.1\%) responders were aware of the advantages of SDF treatment over traditional dental treatment, 35 (15.7\%) and 85 (38.1\%) were somewhat and little aware, respectively. Regarding potential problems associated with the use of SDF, 33 (14.8\%) were not at all aware, while 59 (26.5\%) were aware of such problems.

The attitude of dentists related to the use of SDF treatment was assessed by an 8-item self-reported questionnaire, responses to which are summarized in - Table 4. About 64 (28.7\%) responders agreed that SDF is a better alternative treatment for children with behavioral issues, 74 (33.2\%) agreed that it is a better treatment option for medically fragile patients, and 79 (35.4\%) agreed that it can be used as an alternative for patients with dental anxiety. It was agreed by $82(36.8 \%$ ) responders that SDF is a good treatment option for patients who recently had received chemotherapy radiation therapy. Similarly, 86 (38.6\%) agreed that patients on bisphosphate treatment can also receive SDF treatment and $46(20.6 \%)$ agreed that SDF can be used in patients requiring general anesthesia. About 34 (15.2\%) responders approved that SDF can be used in patients with microstomia, while 133 (59.6\%) said that SDF is a good treatment option for primary

Table 2 Responses by the dentists regarding silver diamine fluoride (SDF) educational experience $(n=223)$

\begin{tabular}{|c|c|c|c|c|c|c|}
\hline & \multicolumn{5}{|c|}{ Responses ( $n \%)$} & \multirow[t]{2}{*}{ Mean \pm SD } \\
\hline & 1 & 2 & 3 & 4 & 5 & \\
\hline $\begin{array}{l}\text { How well were you educated about SDF in dental school in } \\
\text { classroom settings? }\end{array}$ & $\begin{array}{l}138 \\
(61.9)\end{array}$ & $\begin{array}{l}53 \\
(23.8)\end{array}$ & $\begin{array}{l}26 \\
(11.7)\end{array}$ & $\begin{array}{l}6 \\
(2.7)\end{array}$ & $\begin{array}{l}0 \\
(0)\end{array}$ & $1.55 \pm 0.80$ \\
\hline $\begin{array}{l}\text { How well were you educated about SDF in dental school in a } \\
\text { clinical setting? }\end{array}$ & $\begin{array}{l}177 \\
(79.4)\end{array}$ & $\begin{array}{l}38 \\
(17.0)\end{array}$ & $\begin{array}{l}8 \\
(3.6)\end{array}$ & $\begin{array}{l}0 \\
(0)\end{array}$ & $\begin{array}{l}0 \\
(0)\end{array}$ & $1.24 \pm 0.51$ \\
\hline How well were you educated about SDF in your residency? & $\begin{array}{l}187 \\
(83.9)\end{array}$ & $\begin{array}{l}8 \\
(3.6)\end{array}$ & $\begin{array}{l}13 \\
(5.8)\end{array}$ & $\begin{array}{l}15 \\
(6.7)\end{array}$ & $\begin{array}{l}0 \\
(0)\end{array}$ & $1.35 \pm 0.86$ \\
\hline $\begin{array}{l}\text { How well were you educated about SDF after graduation in } \\
\text { continuing education courses? }\end{array}$ & $\begin{array}{l}151 \\
(67.7)\end{array}$ & $\begin{array}{l}46 \\
(20.6)\end{array}$ & $\begin{array}{l}13 \\
(5.8)\end{array}$ & $\begin{array}{l}13 \\
(5.8)\end{array}$ & $\begin{array}{l}0 \\
(0)\end{array}$ & $1.50 \pm 0.84$ \\
\hline $\begin{array}{l}\text { How well were you educated about SDF after graduation with } \\
\text { dental journals/other publications? }\end{array}$ & $\begin{array}{l}120 \\
(53.8)\end{array}$ & $\begin{array}{l}62 \\
(27.8)\end{array}$ & $\begin{array}{l}3 \\
(1.3)\end{array}$ & $\begin{array}{l}38 \\
(17.0)\end{array}$ & $\begin{array}{l}0 \\
(0)\end{array}$ & $1.82 \pm 1.1$ \\
\hline $\begin{array}{l}\text { How well were you educated about SDF after graduation with } \\
\text { online resources? }\end{array}$ & $\begin{array}{l}45 \\
(20.2)\end{array}$ & $\begin{array}{l}85 \\
(38.1)\end{array}$ & $\begin{array}{l}28 \\
(12.6\end{array}$ & $\begin{array}{l}65 \\
(29.1)\end{array}$ & $\begin{array}{l}0 \\
(0)\end{array}$ & $2.51 \pm 1.1$ \\
\hline
\end{tabular}


Table 3 Knowledge of dentists regarding silver diamine fluoride (SDF) treatment uses and potential problems $(n=223)$

\begin{tabular}{|c|c|c|c|c|c|c|}
\hline & \multicolumn{5}{|c|}{ Responses (n\%) } & \multirow[t]{2}{*}{ Mean \pm SD } \\
\hline & 1 & 2 & 3 & 4 & 5 & \\
\hline $\begin{array}{l}\text { How much do you know about what SDF is used for in } \\
\text { dentistry? }\end{array}$ & $\begin{array}{l}53 \\
(23.8)\end{array}$ & $\begin{array}{l}89 \\
(39.9)\end{array}$ & $\begin{array}{l}20 \\
(9.0)\end{array}$ & $\begin{array}{l}61 \\
(27.4)\end{array}$ & $\begin{array}{l}0 \\
(0)\end{array}$ & $2.40 \pm 1.1$ \\
\hline $\begin{array}{l}\text { How much do you know how SDF is used for treatment of } \\
\text { tooth hypersensitivity? }\end{array}$ & $\begin{array}{l}46 \\
(20.6)\end{array}$ & $\begin{array}{l}102 \\
(45.7)\end{array}$ & $\begin{array}{l}21 \\
(9.4)\end{array}$ & $\begin{array}{l}54 \\
(24.2)\end{array}$ & $\begin{array}{l}0 \\
(0)\end{array}$ & $2.37 \pm 1.1$ \\
\hline How SDF is used to treat dental caries in pediatric patients? & $\begin{array}{l}16 \\
(7.2)\end{array}$ & $\begin{array}{l}55 \\
(24.7)\end{array}$ & $\begin{array}{l}51 \\
(22.9)\end{array}$ & $\begin{array}{l}101 \\
(45.3)\end{array}$ & $\begin{array}{l}0 \\
(0)\end{array}$ & $3.06 \pm 0.9$ \\
\hline How SDF is used to treat dental caries in adult patients? & $\begin{array}{l}70 \\
(31.4)\end{array}$ & $\begin{array}{l}77 \\
(34.5)\end{array}$ & $\begin{array}{l}25 \\
(11.2)\end{array}$ & $\begin{array}{l}51 \\
(22.9)\end{array}$ & $\begin{array}{l}0 \\
(0)\end{array}$ & $2.26 \pm 1.1$ \\
\hline $\begin{array}{l}\text { How much do you know what advantages SDF treatment has } \\
\text { over traditional dental treatments? }\end{array}$ & $\begin{array}{l}38 \\
(17.0)\end{array}$ & $\begin{array}{l}85 \\
(38.1)\end{array}$ & $\begin{array}{l}35 \\
(15.7)\end{array}$ & $\begin{array}{l}65 \\
(29.1)\end{array}$ & $\begin{array}{l}0 \\
(0)\end{array}$ & $2.57 \pm 1.1$ \\
\hline $\begin{array}{l}\text { How much do you know what the potential problems SDF } \\
\text { usage are can have? }\end{array}$ & $\begin{array}{l}33 \\
(14.8)\end{array}$ & $\begin{array}{l}84 \\
(37.7)\end{array}$ & $\begin{array}{l}47 \\
(21.1)\end{array}$ & $\begin{array}{l}59 \\
(26.5)\end{array}$ & $\begin{array}{l}0 \\
(0)\end{array}$ & $2.59 \pm 1.0$ \\
\hline
\end{tabular}

Table 4 Attitude of dentists regarding the use of silver diamine fluoride (SDF) treatment $(n=223)$

\begin{tabular}{|c|c|c|c|c|c|c|}
\hline & \multicolumn{5}{|c|}{ Responses (n\%) } & \multirow[t]{2}{*}{ Mean \pm SD } \\
\hline & 1 & 2 & 3 & 4 & 5 & \\
\hline $\begin{array}{l}\text { SDF is a good treatment alternative for restorations in children } \\
\text { with behavioral issues }\end{array}$ & $\begin{array}{l}25 \\
(11.2)\end{array}$ & $\begin{array}{l}81 \\
(36.3)\end{array}$ & $\begin{array}{l}53 \\
(23.8)\end{array}$ & $\begin{array}{l}64 \\
(28.7)\end{array}$ & $\begin{array}{l}0 \\
(0)\end{array}$ & $2.70 \pm 1.0$ \\
\hline $\begin{array}{l}\text { SDF is a good treatment alternative when patients are } \\
\text { medically fragile }\end{array}$ & $\begin{array}{l}27 \\
(12.1)\end{array}$ & $\begin{array}{l}68 \\
(30.5)\end{array}$ & $\begin{array}{l}54 \\
(24.2)\end{array}$ & $\begin{array}{l}74 \\
(33.2)\end{array}$ & $\begin{array}{l}0 \\
(0)\end{array}$ & $2.78 \pm 1.0$ \\
\hline SDF can be used when patients have severe dental anxiety & $\begin{array}{l}18 \\
(8.1)\end{array}$ & $\begin{array}{l}77 \\
(34.5)\end{array}$ & $\begin{array}{l}49 \\
(22.0)\end{array}$ & $\begin{array}{l}79 \\
(35.4)\end{array}$ & $\begin{array}{l}0 \\
(0)\end{array}$ & $2.85 \pm 1.0$ \\
\hline $\begin{array}{l}\text { When patients are undergoing or have recently undergone } \\
\text { radiation therapy or chemotherapy }\end{array}$ & $\begin{array}{l}40 \\
(17.9)\end{array}$ & $\begin{array}{l}61 \\
(27.4)\end{array}$ & $\begin{array}{l}40 \\
(17.9)\end{array}$ & $\begin{array}{l}82 \\
(36.8)\end{array}$ & $\begin{array}{l}0 \\
(0)\end{array}$ & $2.74 \pm 1.1$ \\
\hline $\begin{array}{l}\text { SDF can be used when a patient is on bisphosphonate } \\
\text { medication }\end{array}$ & $\begin{array}{l}27 \\
(12.1)\end{array}$ & $\begin{array}{l}69 \\
(30.9)\end{array}$ & $\begin{array}{l}41 \\
(18.4)\end{array}$ & $\begin{array}{l}86 \\
(38.6)\end{array}$ & $\begin{array}{l}0 \\
(0)\end{array}$ & $2.83 \pm 1.1$ \\
\hline $\begin{array}{l}\text { SDF can be used when a patient needs general anesthesia } \\
\text { otherwise }\end{array}$ & $\begin{array}{l}62 \\
(27.8)\end{array}$ & $\begin{array}{l}81 \\
(36.3)\end{array}$ & $\begin{array}{l}34 \\
(15.2)\end{array}$ & $\begin{array}{l}39 \\
(17.5)\end{array}$ & $\begin{array}{l}7 \\
(3.1)\end{array}$ & $2.32 \pm 1.1$ \\
\hline $\begin{array}{l}\text { SDF can be used in patients with microstomia and difficult } \\
\text { access for dental treatment }\end{array}$ & $\begin{array}{l}46 \\
(20.6)\end{array}$ & $\begin{array}{l}95 \\
(42.6)\end{array}$ & $\begin{array}{l}48 \\
(21.5)\end{array}$ & $\begin{array}{l}34 \\
(15.2)\end{array}$ & $\begin{array}{l}0 \\
(0)\end{array}$ & $2.31 \pm 0.9$ \\
\hline $\begin{array}{l}\text { SDF is a good treatment option for primary teeth when the } \\
\text { lesion is not in the esthetic zone }\end{array}$ & $\begin{array}{l}21 \\
(9.4)\end{array}$ & $\begin{array}{l}41 \\
(18.4)\end{array}$ & $\begin{array}{l}28 \\
(12.6)\end{array}$ & $\begin{array}{l}72 \\
(32.3)\end{array}$ & $\begin{array}{l}61 \\
(27.4)\end{array}$ & $3.50 \pm 1.3$ \\
\hline
\end{tabular}

teeth treatment of patients with primary teeth not in the esthetic zone.

It was found that a higher number of consultants were reported to be well educated regarding SDF treatment during their residency training as compared with demonstrators, house officers, and postgraduate trainees $(p<0.001)$. Similarly, a higher number of consultants were aware of the use of SDF treatment in dentistry practice as compared with dental professionals who were at a junior level of training $(p<0.001)$. At the same time, consultants were more commonly reported to be knowing the use of SDF in the treatment of dentinal hypersensitivity $(p<0.001)$. The consultants also seemed to have more knowledge and awareness of how to make use of SDF in patients with behavioral issues $(p<0.001)$ and also the dental treatment of patients who exhibit severe dental anxiety $(p<0.001)$. Consultants considered SDF a good treatment option for patients on chemotherapy/radiation therapy $(p<0.001)$ or those on bisphosphonate drugs $(p<0.001)$, compared with demonstrators, house officers, and postgraduate trainees. They were also aware more of the benefits of SDF treatment over traditional therapies in patients with microstomia and difficult access $(p<0.001)$. They were more aware of potential problems associated with SDF treatment. Age, gender, 
and working in rural/urban settings were found to have no significant associations with the education, knowledge, or attitude of responders regarding SDF treatment.

\section{Discussion}

The aim of this study was to assess the knowledge, experience, and professional expertise of dentists regarding the use of SDF. Regarding SDF educational experience, 138 (61.9\%) reported that no education was provided about this subject in classroom settings while $177(79.4 \%)$ reported no education was provided in clinical settings. These percentages are not unexpected because the Food Drug Addiction (FDA) had recommended the use of SDF for the treatment of dentine sensitivity in 2014. Another study conducted in a U.S. dental school by Mario et al reported that $91 \%$ of the respondents were not at all educated about SDF in classroom settings and 95\% not in clinical settings. ${ }^{13}$

In Pakistan, the field of pediatric dentistry is new and developing ${ }^{14}$ and second SDF is not taught in undergraduate dental curricula approved by the Pakistan Medical Council (PMC). Therefore, there is an urgent need to develop a structured undergraduate pediatric dental curriculum. During continuing education programs, 72 (32.2\%) responders reported the provision of educational information about SDF. This rise in SDF education is likely to increase as The American Academy of Pediatric Dentistry (AAPD) has recommended its use. ${ }^{15}$

Despite respondents having less education regarding SDF in undergraduate programs, most of them (76.2\%) were aware of SDF use in dentistry. This can be due to their well-established professional development programs in place. In our study, the majority of the respondents (92.8\%) were aware of SDF use for the treatment of pediatric dental caries, which is well supported by the literature. ${ }^{16-18}$ Around $65(29.1 \%)$ responders were aware of the advantages of SDF treatment over traditional dental treatment. These findings are comparable with another study by Crystal et al. ${ }^{12}$ Regarding the problems associated with the use of SDF, 59 respondents $(26.5 \%)$ were well aware of such problems. The findings of one of the studies by Crystal et al supported the fact that parents are convinced to use SDF treatment despite associated problems with it, but the location of the lesion is a deciding factor. Staining on posterior teeth was more acceptable (68\%) than staining on anterior teeth (30\%). ${ }^{19}$

The respondents agreed that SDF is a better alternative treatment for children with behavioral issues, medically fragile patients, patients with dental anxiety, patients on chemotherapy radiation therapy, patients on bisphosphate treatment, and for primary teeth. These findings are like the studies present in the literature. ${ }^{6,10,20}$ The practice of SDF was related to the workplace, experience, and specialty among dentists who agreed to participate in our study. This study supported the fact that dentists working at universities as consultants or on academic appointments had more educational knowledge of the use of SDF, compared with those who are self-employed; and the principal barrier to SDF use was a lack of knowledge. ${ }^{21}$ This might be due to the gap between research and clinical practice. Mostly, dentists working as consultants in the academic environment have earlier and easy availability of evidence-based practice, which gives them knowledge and safety protocol to use new materials and procedures with much ease. ${ }^{22}$

\section{Conclusion}

Silver diamine fluoride (SDF) is not a common material used by dentists. Many respondents had acquired their knowledge regarding SDF through professional development such as continuing education courses, dental journals, and online resources. Therefore, it is the need of time to put all educational efforts together to enhance knowledge regarding the use, advantages, and potential problems of SDF. With the increase in the knowledge of respondents, they will have a more positive attitude toward the application of SDF in their practices. Increasing SDF educational efforts might therefore result in increased utilization of this new material and technique, especially in children.

\section{Consent}

Informed consent was obtained from the participants after explaining to them the research objective and aim, voluntary participation, right to autonomy and confidentiality, and the right to withdraw from participation in the study.

\section{Ethical Approval}

This study was approved by The University Research Committee with approval number (ERB Number: UCD/ERCA/20/04 g) and ensured the ethical conduct of the study issued on 2021.

\section{Authors' Contributions}

BA conceived and designed the study, conducted research, provided research materials, and collected and organized data. SA, FS, and FF collected and analyzed, and interpreted the data. MW and ZK provided logistic support and collected data. All authors were involved in writing the initial and final draft of the manuscript. All authors have critically reviewed and approved the final draft and are responsible for the content and similarity index of the manuscript.

\section{Conflict of Interest}

None declared.

\section{References}

1 Gruythuysen RJM. Non-restorative cavity treatment: should this be the treatment of choice? Reflections of a teacher in paediatric dentistry. Dent Update 2019;46(03):220-228

2 Jiang M, Mei ML, Wong MCM, Chu CH, Lo ECM. Effect of silver diamine fluoride solution application on the bond strength of dentine to adhesives and to glass ionomer cements: a systematic review. BMC Oral Health 2020;20(01):40

3 Crystal YO, Niederman R. Evidence-based dentistry update on silver diamine fluoride. Dent Clin North Am 2019;63(01):45-68 
4 Kumar A, Cernigliaro D, Northridge ME, et al. A survey of caregiver acculturation and acceptance of silver diamine fluoride treatment for childhood caries. BMC Oral Health 2019;19(01):228

5 Magno MB, Silva LPD, Ferreira DM, Barja-Fidalgo F, FonsecaGonçalves A. Aesthetic perception, acceptability and satisfaction in the treatment of caries lesions with silver diamine fluoride: a scoping review. Int J Paediatr Dent 2019;29(03):257-266

6 Seifo N, Robertson M, Maclean J, et al. The use of silver diamine fluoride (SDF) in dental practice. Br Dent J 2020;228(02):75-81

7 Patel J, Anthonappa RP, King NM. Silver diamine fluoride: a critical review and treatment recommendations. Dent Update 2019;46 (07):626-633

8 Sabbagh H, Othman M, Khogeer L, Al-Harbi H, Al Harthi A, Abdulgader Yaseen Abdulgader A. Parental acceptance of silver diamine fluoride application on primary dentition: a systematic review and meta-analysis. BMC Oral Health 2020;20(01):227

9 Vollú AL, Rodrigues GF, Rougemount Teixeira RV, et al. Efficacy of $30 \%$ silver diamine fluoride compared to atraumatic restorative treatment on dentine caries arrestment in primary molars of preschool children: a 12-months parallel randomized controlled clinical trial. J Dent 2019;88(January):103165. Doi: 10.1016/j. jdent.2019.07.003

10 Abdellatif HM, Ali AM, Baghdady SI, ElKateb MA. Caries arrest effectiveness of silver diamine fluoride compared to alternative restorative technique: randomized clinical trial. Eur Arch Paediatr Dent 2021;22(04):575-585

11 Firouzmandi M, Shafiei F, Jowkar Z, Nazemi F. Effect of silver diamine fluoride and proanthocyanidin on mechanical properties of caries-affected dentin. Eur J Dent 2019;13(02):255-260

12 Crystal YO, Janal MN, Yim S, NelsonT. Teaching and utilization of silver diamine fluoride and Hall-style crowns in US pediatric dentistry residency programs. J Am Dent Assoc 2020;151(10):755-763

13 Antonioni MB, Fontana M, Salzmann LB, Inglehart MR. Pediatric dentists' silver diamine fluoride education, knowledge, attitudes, and professional behavior: a national survey. J Dent Educ 2019;83 (02):173-182

14 Khan FR, Mahmud S, Rahman M. The need of paediatric dentistry specialists in Pakistan. J Coll Physicians Surg Pak 2013;23(04): 305-307

15 Crystal YO, Marghalani AA, Ureles SD, et al. Use of silver diamine fluoride for dental caries management in children and adolescents, including those with special health care needs. Pediatr Dent 2017;39(05):135-145

16 Gao SS, Zhao IS, Hiraishi N, et al. Clinical trials of silver diamine fluoride in arresting caries among children: a systematic review. JDR Clin Trans Res 2016;1(03):201-210

17 Gao Z, Ying S, Liu J, Zhang H, Li J, Ma C. A cross-sectional study: comparing the attitude and knowledge of medical and nonmedical students toward 2019 novel coronavirus. J Infect Public Health 2020;13(10):1419-1423

18 Chibinski AC, Wambier LM, Feltrin J, Loguercio AD, Wambier DS, Reis A. Silver diamine fluoride has efficacy in controlling caries progression in primary teeth: a systematic review and metaanalysis. Caries Res 2017;51(05):527-541

19 Crystal YO, Kreider B, Raveis VH. Parental expressed concerns about silver diamine fluoride (SDF) treatment. J Clin Pediatr Dent 2019;43(03):155-160

20 Contreras V, Toro MJ, Elías-Boneta AR, Encarnación-Burgos A. Effectiveness of silver diamine fluoride in caries prevention and arrest: a systematic literature review. Gen Dent 2017;65(03):22-29

21 Chałas R, Wójcik-Chęcińska I, Zamościńska J, Bachanek T. Assessment of pain intensity in patients with dentin hypersensitivity after application of prophylaxis paste based on calcium sodium phosphosilicate formula. Med Sci Monit 2015;21:2950-2955

22 Vollú AL, Moreira Jde L, Luiz RR, Barja-Fidalgo F, Fonseca-Gonçalves A. Survey of knowledge, attitudes and practices of brazilian dentists regarding silver diamine fluoride. Pesqui Bras Odontopediatria Clin Integr 2019;20:1-7 